\title{
The Expression of Two Splice Variants of the Kv3.1 Potassium Channel Gene Is Regulated by Different Signaling Pathways
}

\author{
Si-qiong J. Liu and Leonard K. Kaczmarek \\ Department of Pharmacology, Yale University School of Medicine, New Haven, Connecticut 06520-8066
}

The Kv3.1 potassium channel gene gives rise to two different channel proteins, Kv3.1a and Kv3.1b, by alternative splicing of nuclear RNA. During development the levels of Kv3.1b mRNA (but not Kv3.1a) substantially increase in rat cerebellum after postnatal day 8 . The molecular mechanism underlying the differential regulation of the two transcripts is not known. Using in vitro slices of cerebellum, we have found that basic fibroblast growth factor (bFGF) upregulates both Kv3.1a and Kv3.1b at this developmental stage, but that depolarization by elevated potassium concentrations is without effect. Combined treatment with bFGF and depolarization, however, prevents the increase in Kv3.1a transcripts and selectively increases Kv3.1b mRNA levels. A protein kinase $C$ (PKC) inhibitor blocks the increase in Kv3.1a mRNA levels induced by bFGF alone but does not affect the increase in Kv3.1b mRNA. Measurement of nuclear protein kinase $\mathrm{C}$ activity shows that bFGF activates this enzyme and that depolarization blocks this activation. In contrast to these findings at postnatal day 8, bFGF fails to alter Kv3.1 transcripts in slices from adult animals, and PKC activity is enhanced rather than suppressed by depolarization. Our results indicate that different signaling pathways regulate Kv3.1a and Kv3.1b expression and suggest that Kv3.1a mRNA levels may be modulated by neuronal activity.

Key words: Kv3.1 potassium channels; transcription; splice variants; depolarization; protein kinase $C$; cerebellum
The excitable properties of neurons undergo dynamic changes during development. One of the mechanisms underlying such changes is the regulation of the levels of potassium channels. Although developmental changes in potassium channels have been documented, the molecular events that control channel expression during development are largely unknown. One of the potassium channels that plays an important role in regulating the excitability of neurons that are required to fire at high frequency is the Shaw family voltage-gated channel, Kv3.1.

By alternative splicing the Kv3.1 gene generates two different transcripts, Kv3.1a and Kv3.1b. The predicted protein sequences of Kv3.1a and Kv3.1b differ at the C terminus (Luneau et al., 1991). Both the Kv3.1a and Kv3.1b channels, when expressed in a variety of cell types, produce high-threshold, noninactivating, delayed rectifier currents (Yokoyama et al., 1989; Kanemasa et al., 1995). The Kv3.1 protein is expressed in a subpopulation of neurons in the brain and in a subset of T-lymphocytes (Grissmer et al., 1992; Perney et al., 1992; Weiser et al., 1995). Immunohistochemical studies reveal that $\mathrm{Kv} 3.1 \mathrm{~b}$ protein is present in patches in the somata and synaptic termini (Weiser et al., 1995; Perney and Kaczmarek, 1997). It has been suggested that repolarization of action potentials by Kv3.1-like currents minimizes the relative refractory period, enabling these neurons to fire at increased frequencies.

$\mathrm{Kv} 3.1 \mathrm{a}$ and $\mathrm{Kv} 3.1 \mathrm{~b}$ are expressed in the same neurons, and the spatial expression patterns of these transcripts in brain slices

Received Jan. 23, 1998; accepted Jan. 27, 1998.

This work was supported by National Institutes of Health Grant DC-01919 (L.K.K.) and a National Research Service Award postdoctoral fellowship (S.J.L.). We thank Drs. Neil Magoski, Matthew Whim, and Benjamin White for helpful discussions and Dr. Li Gan for technical advice.

Correspondence should be addressed to Si-qiong J. Liu, Department of Pharmacology, Yale University School of Medicine, 333 Cedar Street, New Haven, CT 06520-8066.

Copyright (C) 1998 Society for Neuroscience $\quad 0270-6474 / 98 / 182881-10 \$ 05.00 / 0$ appear indistinguishable (Perney et al., 1992). The temporal expression of these splice variants, however, differs during development. Kv3.1a is the predominant transcript in developing neurons and shows only a moderate increase in its levels of expression throughout development. In contrast, a pronounced increase in Kv3.1b occurs from postnatal day 8 to postnatal day 14, and the Kv3.1b transcript predominates in adult neurons.

Studies using AtT20 cells indicate that both basic fibroblast growth factor (bFGF) and depolarization evoke an increase in the levels of Kv3.1 mRNA (Perney and Kaczmarek, 1993). The promoter of the Kv3.1 gene has been shown to contain a cAMP response element-binding protein binding site that can be activated by cAMP and calcium (Gan et al., 1996). Interestingly, transfection of AtT20 cells with activated ras results in a selective increase in the expression of Kv3.1a mRNA (Hemmick et al., 1992), suggesting that ras may be involved in the differential regulation of Kv3.1 transcripts. Whether these factors are involved in the regulation of Kv3.1 expression in developing neurons is, however, not yet known.

Because Kv3.1 mRNA and protein are present in cerebellar granule cells at a very high level (Perney et al., 1992; Weiser et al., 1995), we have used in vitro slices of cerebellum as a model system to study the factors that control the differential regulation of these Kv3.1 splice variants during development.

\section{MATERIALS AND METHODS}

Preparation and incubation of slices of cerebellum. The cerebellum was removed from decapitated 3- to 30-d-old Sprague Dawley rats and placed in standard artificial CSF (ACSF; in mM: $125 \mathrm{NaCl}, 2.5 \mathrm{KCl}, 26$ $\mathrm{NaHCO}_{3}, 1.25 \mathrm{NaH}_{2} \mathrm{PO}_{4}, 2 \mathrm{CaCl}_{2}, 1 \mathrm{MgCl}_{2}$, and 10 glucose, $\mathrm{pH} 7.4$ ) that was gassed with a $95 \% \mathrm{O}_{2}-5 \% \mathrm{CO}_{2}$ mixture. Slices $(300-500 \mu \mathrm{m})$ were cut in ice-cold ACSF solution and were then transferred to either ACSF or high-K ACSF (in mM: $77.5 \mathrm{NaCl}$ and $50 \mathrm{KCl}$ ) at room temperature for various treatments with neurotrophins and inhibitors. Human recombinant bFGF, brain-derived neurotrophic factor (BDNF), and neurotrophin-3 (NT-3) were obtained from Calbiochem (La Jolla, 
Table 1. The effects of incubation of cerebellar slices in ACSF on deoxyglucose uptake

Deoxyglucose uptake at room temperature/deoxyglucose uptake at $0^{\circ} \mathrm{C}$

\begin{tabular}{|c|c|c|c|c|c|c|c|c|}
\hline \multirow[b]{2}{*}{ Treatment } & \multicolumn{2}{|l|}{ P3 } & \multicolumn{2}{|l|}{ P8 } & \multicolumn{2}{|l|}{$\mathrm{P} 15$} & \multicolumn{2}{|l|}{ P31 } \\
\hline & Mean $\pm \mathrm{SE}$ & $n$ & Mean $\pm \mathrm{SE}$ & $n$ & Mean $\pm \mathrm{SE}$ & $n$ & Mean $\pm \mathrm{SE}$ & $n$ \\
\hline No treatment & $3.49 \pm 1.14$ & 3 & $3.35 \pm 1.03$ & 3 & $3.60 \pm 0.68$ & 3 & $2.61 \pm 0.57$ & 3 \\
\hline $\mathrm{ACSF}(6 \mathrm{hr})$ & $3.05 \pm 1.35$ & 3 & $4.31 \pm 0.93$ & 2 & $3.28 \pm 0.11$ & 3 & $2.87 \pm 0.57$ & 3 \\
\hline
\end{tabular}

CA), Promega (Madison, WI), and Alamone, respectively. H-89, $N$-acetyl-S-farnesyl-L-cystein (AFC), bisindolylmaleimide I (BIM I), KT-5720, KN-62, and phorbol 12-myristate 13-acetate were obtained from Calbiochem.

Deoxyglucose uptake assay. To test the viability of cerebellar slices incubated in ACSF, we measured their uptake of 2-deoxy-[1- $\left.{ }^{3} \mathrm{H}\right]$-glucose $\left(\left[{ }^{3} \mathrm{H}\right] \mathrm{DG}\right.$; Amersham, Arlington Heights, IL). This technique has been widely used to evaluate the activity of CNS neurons (Sokoloff et al., 1977). Cerebellums were dissected from rats and then weighed and sliced. Half of the slices were incubated with $\left[{ }^{3} \mathrm{H}\right] \mathrm{DG}$ in $\mathrm{ACSF}$ at $0^{\circ} \mathrm{C}$, and the other half were incubated at room temperature, both for $40 \mathrm{~min}$. The slices were then washed three times with ice-cold ACSF and homogenized in $1 \%$ SDS, and the homogenates were incubated with $100 \mathrm{U}$ of DNase (Boehringer Mannheim, Indianapolis, IN) at $37^{\circ} \mathrm{C}$ for $20 \mathrm{~min}$. The levels of $\left[{ }^{3} \mathrm{H}\right] \mathrm{DG}$ were then measured by liquid scintillation counting. The ratio of $\left[{ }^{3} \mathrm{H}\right] \mathrm{DG}$ uptake at room temperature relative to that at $0^{\circ} \mathrm{C}\left(\mathrm{R}_{\mathrm{DG}}\right)$ was used to evaluate the viability of slices (Table 1$)$. In a separate series of experiments, slices were incubated in gassed ACSF for $6 \mathrm{hr}$ before the $\left[{ }^{3} \mathrm{H}\right] \mathrm{DG}$ uptake assay. Previous incubation of slices in ACSF for up to $6 \mathrm{hr}$ did not affect $\left[{ }^{3} \mathrm{H}\right] \mathrm{DG}$ uptake, because $\mathrm{R}_{\mathrm{DG}}$ values from these slices were not significantly different from those of the controls (Table 1). These data indicate that cerebellar slices from postnatal rats remain viable for $6 \mathrm{hr}$ in ACSF.

$R$ Nase protection assay. Cerebellums were collected immediately after each rat was killed $(t=0)$ or after $6 \mathrm{hr}$ incubation in ACSF. Total RNA was isolated from each sample by the guanidinium thiocyanateacid-phenol-chloroform method (Chomcyznski and Sacchi, 1987), and RNA concentrations were measured using a spectrophotometer. Plasmid DNA containing the coding region of the Kv3.1b gene subcloned into pGEM-A (Luneau et al., 1991) was digested with $P v u I I$. $\left[{ }^{32} \mathrm{P}\right] \mathrm{C}$ TP-labeled antisense RNA probe was transcribed with SP6 polymerase, using the linearized plasmid as the DNA template. This probe (413 bp) is complementary to 108 bases of the $3^{\prime}$ end of Kv3.1a and to 398 bases of Kv3.1b mRNA (Perney et al., 1992) and was used to measure the levels of the Kv3.1a and Kv3.1b transcripts. Linearized pTRI-GAPDH-rat (Ambion) was used as a DNA template to generate an antisense mRNA (434 bp) that hybridized with a 316 base fragment of glyceraldehyde 3-phosphate dehydrogenase (GAPDH) RNA, a housekeeping enzyme. The levels of GAPDH mRNA were measured and used as an internal control. The RNase protection assay was performed using published procedures (Ausubel et al., 1990). Ten micrograms of total RNA isolated from cerebellum of postnatal day 3 , 8,15 , or 33-40 or tRNA (as a control) was hybridized with $\left[{ }^{32} \mathrm{P}\right] \mathrm{CTP}$ labeled antisense RNA probes.

The amount of radioactivity in each band was visualized by autoradiography and was quantified on a densitometer by integrating the area under the peak. To determine the range of densitometric readings that were linearly proportional to the radioactivity of the bands, the radioactivity of bands containing different amounts of $\left[{ }^{32} \mathrm{P}\right] \mathrm{CTP}$ was quantified on a densitometer and then counted in liquid scintillation counter. The densitometric readings of bands, ranging from 500 to $7000 \mathrm{U}$, increased linearly with the level of radioactivity (up to $250,000 \mathrm{cpm}$ ). Therefore, in each experiment the gel was exposed to x-ray film for varying lengths of time. Only when the densitometric intensity values of the Kv3.1- and GAPDH-protected bands were within this linear range was the data used for further analysis. The ratio of the intensity of the Kv3.1a or Kv3.1b band to the intensity of the GAPDH band was used to determine the relative levels of Kv3.1a and Kv3.1b mRNA. Because there was variability in the specific activity of the GAPDH probe between experiments, the changes in the Kv3.1a and Kv3.1b mRNA levels were determined within each experiment. We calculated the average values of relative levels of Kv3.1a and Kv3.1b mRNA in the ACSF control sample and compared the value of each treated sample with this control. Changes in the Kv3.1a and Kv3.1b mRNA levels were then calculated as follows:

\section{$\left(\frac{\mathrm{Kv} 3.1 \mathrm{a} \text { or } \mathrm{b}(\text { treated or } \mathrm{ACSF}) / \mathrm{GAPDH}(\text { treated or ACSF })}{\mathrm{Av}[\mathrm{Kv} 3.1 \mathrm{a} \text { or } \mathrm{b}(\mathrm{ACSF}) / \mathrm{GAPDH}(\mathrm{ACSF})]}-1\right)$}

$\times 100 \%$.

Isolation of nuclei and assay of protein kinase $C$ activity. Nuclei were isolated from cerebellar slices according to the method of Thompson (1987). In brief, after each treatment the slices were briefly centrif uged and then resuspended in 8 volumes of ice-cold $2.1 \mathrm{M}$ sucrose solution containing $1 \mathrm{~mm} \mathrm{MgCl}_{2}, 10 \mathrm{~mm}$ Tris, $10 \mathrm{~mm}$ EDTA, $1 \mathrm{~mm}$ dithiothreitol, $0.42 \mu \mathrm{g} / \mathrm{ml}$ pepstatin, $0.83 \mu \mathrm{g} / \mathrm{ml}$ leupeptin, $0.83 \mu \mathrm{g} / \mathrm{ml}$ aprotinin, and 0.2 $\mathrm{mm}$ phenylmethanesulfonyl fluoride (PMSF), $\mathrm{pH}$ 7.4. The suspension was then homogenized using a loose-fitting Dounce homogenizer. The homogenate was centrifuged at $64,000 \times g$ for $30 \mathrm{~min}$ at $4^{\circ} \mathrm{C}$ in a swinging bucket rotor. The nuclear pellets were resuspended in an ice-cold lysate buffer $(20 \mathrm{~mm}$ Tris, $5 \mathrm{~mm}$ EDTA, $10 \mathrm{~mm}$ EGTA, 0.3\% $\beta$-mercaptoethanol, $1 \mathrm{~mm}$ PMSF, and $10 \mathrm{~mm}$ benzamidine, $\mathrm{pH} 7.4$ ), sonicated for $30 \mathrm{sec}$, and then centrifuged at $100,000 \times g$ for $60 \mathrm{~min}$ at $4^{\circ} \mathrm{C}$. The protein concentration of the supernatant was determined using the Bio-Rad (Hercules, CA) protein determination reagent.

Nuclear protein kinase C (PKC) activity was detected using a protein kinase kit (Calbiochem) following the manufacturer's instructions. The total activity was determined in the presence of calcium and phosphatidylserine, and the nonspecific activity was measured in the presence of 2 mM EGTA and in the absence of phosphatidylserine. PKC activity was calculated by subtracting the nonspecific activity from the total activity. The activity of $\mathrm{Na}^{+}-\mathrm{K}^{+}$-ATPase (picomoles of ${ }^{32} \mathrm{P}$ per hour per milligram of protein) was tested in the initial homogenate and in purified nuclear fractions, as described by Post and Sen (1987), and the amount of inorganic phosphate released during the assay was measured according to the method of Ames (1966). $\mathrm{Na}^{+}-\mathrm{K}^{+}$-ATPase activity was $6.1 \pm 0.8$ pmol of ${ }^{32} \mathrm{P} \cdot \mathrm{hr}^{-1} \cdot \mathrm{mg}$ of protein ${ }^{-1}(n=8)$ in the nuclear fraction and $28.7 \pm 1.1 \mathrm{pmol} \cdot \mathrm{hr}^{-1} \cdot \mathrm{mg}^{-1}$ in the initial homogenate.

To measure the PKC activity of cerebellar homogenates, slices were centrifuged briefly and then resuspended and homogenized in the icecold lysate buffer with a Dounce homogenizer. The homogenates were then sonicated for $30 \mathrm{sec}$ and centrifuged at $100,000 \times g$ for $60 \mathrm{~min}$ at $4^{\circ} \mathrm{C}$. The protein concentrations of the supernatant were determined as above. The reaction mix contained $5 \mu \mathrm{g}$ of protein, $20 \mu \mathrm{M}$ Tris- $\mathrm{HCl}, \mathrm{pH}$ $7.5,10 \mu \mathrm{g} / \mathrm{ml}$ phosphatidylserine (Sigma, St. Louis, MO), $1 \mu \mathrm{g} / \mathrm{ml}$ diolein (ICN Biochemicals, Costa Mesa, CA), $0.1 \mathrm{mM} \mathrm{Ca}^{2+}, 10 \mu \mathrm{M}\left[\gamma^{-32} \mathrm{P}\right] \mathrm{ATP}$ (100-200 cpm/pmol, Amersham), and $300 \mu \mathrm{g} / \mathrm{ml}$ histone H1 (Sigma). Nonspecific activity was measured in the presence of 2 mM EGTA and in the absence of phosphatidylserine. Specific activity was calculated as (total activity - nonspecific activity)/milligram of protein. PKC activity was also determined in the presence of phorbol 12-myristate 13-acetate (PMA), which activates the classical PKC and nPKC isoforms (but not the atypical isoforms) (Tanaka and Nishizuka, 1994). The PKC assay was performed at $30^{\circ} \mathrm{C}$ for $5 \mathrm{~min}$ as described by Wang and Roach (1993). For those experiments in which the PKC activity of combined homogenates was measured, the homogenates of the samples were premixed and left at room temperature for $10 \mathrm{~min}$ before the assay of PKC.

Data analysis. Each RNA or protein sample was analyzed in triplicate, and the mean value was used for further analysis. The $n$ value in figure legends refers to the number of independent sample preparations, and all data are presented as mean \pm SEM. The statistical tests used and the results of these tests are presented in each figure legend. 


\section{RESULTS}

\section{Changes in the levels of Kv3.1a and Kv3.1b mRNA during development}

We measured the levels of Kv3.1a and Kv3.1b mRNA in cerebellum at different developmental stages using an RNase protection assay. Kv3.1a was the dominant form during the early postnatal period, whereas the levels of Kv3.1b mRNA exceeded those of Kv3.1a after postnatal day 15 (P15) (Fig. 1). Relative to the levels at P8, there were fourfold and eightfold increases in Kv3.1b mRNA at P15 and P40, respectively. In contrast, there was relatively little change in the levels of the Kv3.1a transcript over the same period.

\section{Regulation of Kv3.1 transcripts by FGF and neurotrophins}

The growth factors bFGF, BDNF, and NT-3, as well as the receptors for these factors, are present in developing cerebellum between P3 and P40 and undergo changes in their levels over this period. To investigate possible mechanisms that underlie the developmental regulation of Kv3.1 mRNA levels, we examined the effects of these factors and of depolarization on the expression of Kv3.1a and Kv3.1b mRNAs during development using an in vitro slice preparation. We first tested the viability of cerebellar slices in ACSF by measuring uptake of 2-deoxyglucose and found that cerebellar slices appeared to remain viable in ACSF for at least $6 \mathrm{hr}$ at all the ages tested (Table 1). We also examined whether in vitro incubation by itself changed the levels of Kv3.1 expression and found that the ratio of mRNA levels after incubation in ACSF for $6 \mathrm{hr}$ to that of control is $0.92 \pm 0.08(n=35)$ for Kv3.1a and $0.95 \pm 0.06(n=36)$ for Kv3.1b (Fig. $2 A)$. Thus, incubation in ACSF for $6 \mathrm{hr}$ did not affect the levels of Kv3.1a and Kv3.1b mRNA.

In the following experiments, cerebellar slices from animals at $\mathrm{P} 3, \mathrm{P} 8, \mathrm{P} 15$, and P33-P40 were incubated in ACSF or ACSF containing BDNF, NT-3, or bFGF for $6 \mathrm{hr}$ at room temperature. The levels of Kv3.1a and Kv3.1b mRNA were subsequently determined using an RNase protection assay. The neurotrophin BDNF enhanced the expression of Kv3.1b mRNA at P3 but had very little effect at P8 or in older animals (Table 2). NT-3 selectively increased the levels of the Kv3.1a transcript at P3 (Table 2). Unlike BDNF, bFGF induced a marked increase in the levels of the Kv3.1a and Kv3.1b transcripts at P8 but not at other times (Fig. $2 A, B$ ). These results suggest that each of these factors preferentially upregulates Kv3.1 mRNA levels at different developmental stages.

To test the possible role of neuronal activity in the regulation of Kv3.1 mRNA expression during development, slices were depolarized by a solution in which the potassium concentration was elevated from 2.5 to $50 \mathrm{~mm}$ (high-K ACSF). This treatment did not significantly alter Kv3.1 mRNA levels (Table 2). Because NT-3 treatment selectively elevated Kv3.1a mRNA levels at P3, NT-3 may be partially responsible for the increase that usually occurs in the expression levels of Kv3.1a mRNA after P3. However, the actions of BDNF, NT-3, bFGF, and depolarization alone cannot explain the marked increase in the levels of the Kv3.1b transcript compared with the relatively smaller changes in Kv3.1a mRNA levels after P8.

\section{Differential regulation of Kv3.1 splice variants by FGF and depolarization}

Differential regulation of the expression of the Kv3.1 splice variants occurs during the period from P8 to P15, when granule cells
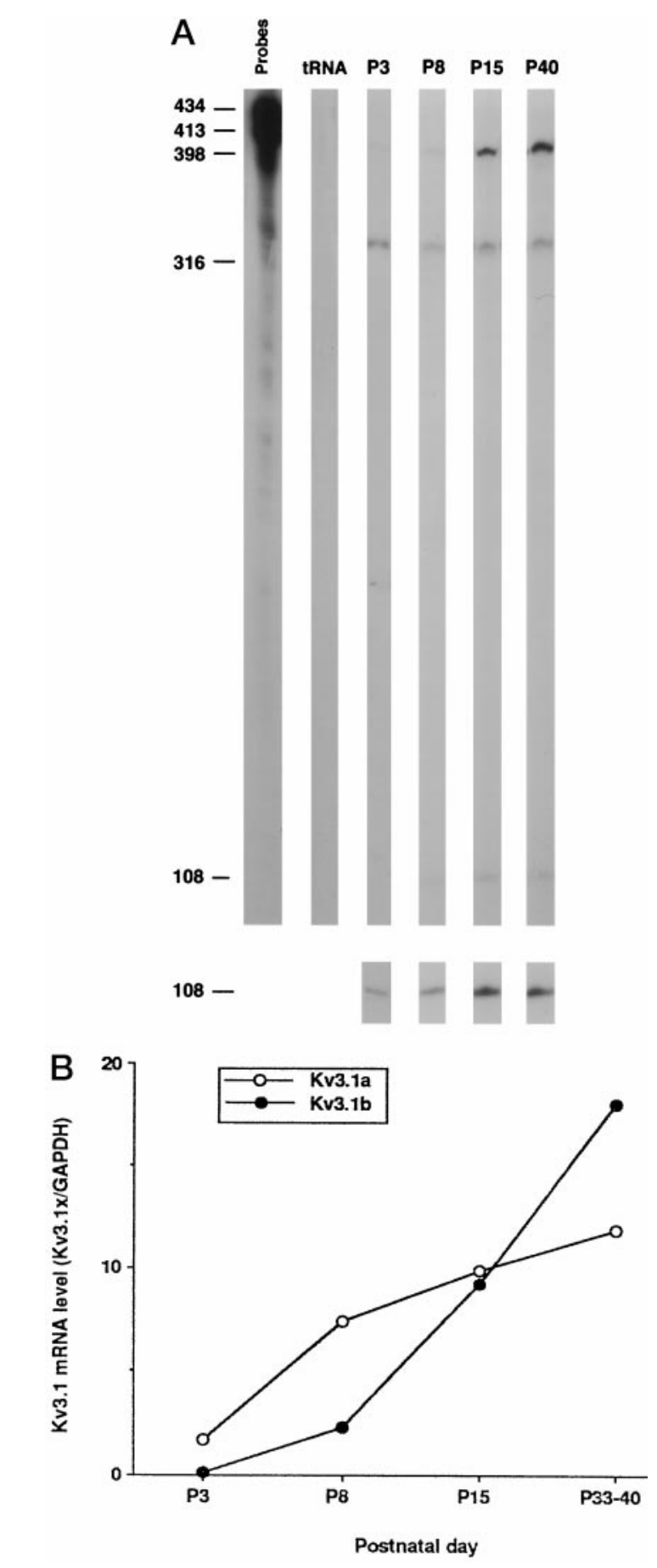

Figure 1. Expression levels of Kv3.1a and Kv3.1b mRNA during development. $A$, RNase protection analysis of Kv3.1a and Kv3.1b mRNA. The protected bands at 398, 316, and 108 nucleotides correspond to Kv3.1b, GAPDH, and Kv3.1a mRNAs, respectively. The bottom panel shows the Kv3.1 band visualized after a longer exposure to film. $B$, Densitometric measurements of the relative amounts of the Kv3.1a and Kv3.1b mRNAs. The intensities of Kv3.1a bands were multiplied by 3.6 to account for the differences in the number of labeled $\mathrm{C}$ residues in the protected bands of Kv3.1a and Kv3.1b, as described previously (Perney et al., 1992). The levels of the Kv3.1a and Kv3.1b mRNA are normalized to the total amount of GAPDH mRNA. Each point is the mean of two measurements from a single experiment. 
A

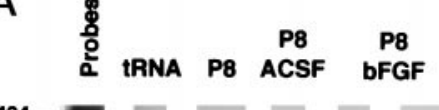

$\begin{aligned} & 434- \\ & 413- \\ & 398- \\ & \end{aligned}$
$316-$

Figure 2. Modulation of Kv3.1 mRNA levels by bFGF during development. $A$, Effects of bFGF on the levels of the Kv3.1a and Kv3.1b mRNA detected by an RNase protection assay at postnatal days 8 and 15 . Total RNA was isolated from cerebellums immediately after slice preparation from cerebellar slices incubated in ACSF and from slices treated with 100 $\mathrm{ng} / \mathrm{ml} \mathrm{bFGF}$ in ACSF for $6 \mathrm{hr}$ at room temperature. The bands corresponding to Kv3.1b, GAPDH, and Kv3.1a mRNAs are 398, 316, and 108 nucleotides, respectively. $B$, Summary of the effects of bFGF on the Kv3.1a and Kv3.1b mRNA levels at P3, P8, and P15. All values are mean \pm SEM. The changes in Kv3.1a and Kv3.1b mRNA levels at P8 are significantly different from $0 ; p<0.01$ and $p<0.05$, respectively. The changes in Kv3.1a and Kv3.1b mRNA levels are also significantly different by ANOVA testing among these age groups, with $p<0.05$. A Tukey-Kramer multiplecomparisons test showed that the change in $\mathrm{Kv} 3.1 \mathrm{~b}$ mRNA expression at P8 was significantly different from that at P3, and that the change in the Kv3.1a mRNA levels at P8 was significantly different from that at $\mathrm{P} 3$ and $\mathrm{P} 15 ; p<0.05$. The $n$ values for Kv3.1a were 5 at $\mathrm{P} 3,4$ at $\mathrm{P} 8$, and 3 at $\mathrm{P} 15$. The $n$ values for $\mathrm{Kv} 3.1 \mathrm{~b}$ at $\mathrm{P} 3, \mathrm{P} 8$, and $\mathrm{P} 15$ were 5,5 , and 3 , respectively.

migrate from the external germinal layer to the internal granule layer and form synapses with mossy fibers. This raises the possibility that depolarization may play a role in the selective elevation of Kv3.1b mRNA. We therefore examined whether depolarization could modulate the FGF-induced increase in Kv3.1 transcripts. Although depolarization by itself did not affect Kv3.1 mRNA levels at P8 (Table 2), the combined treatment of bFGF
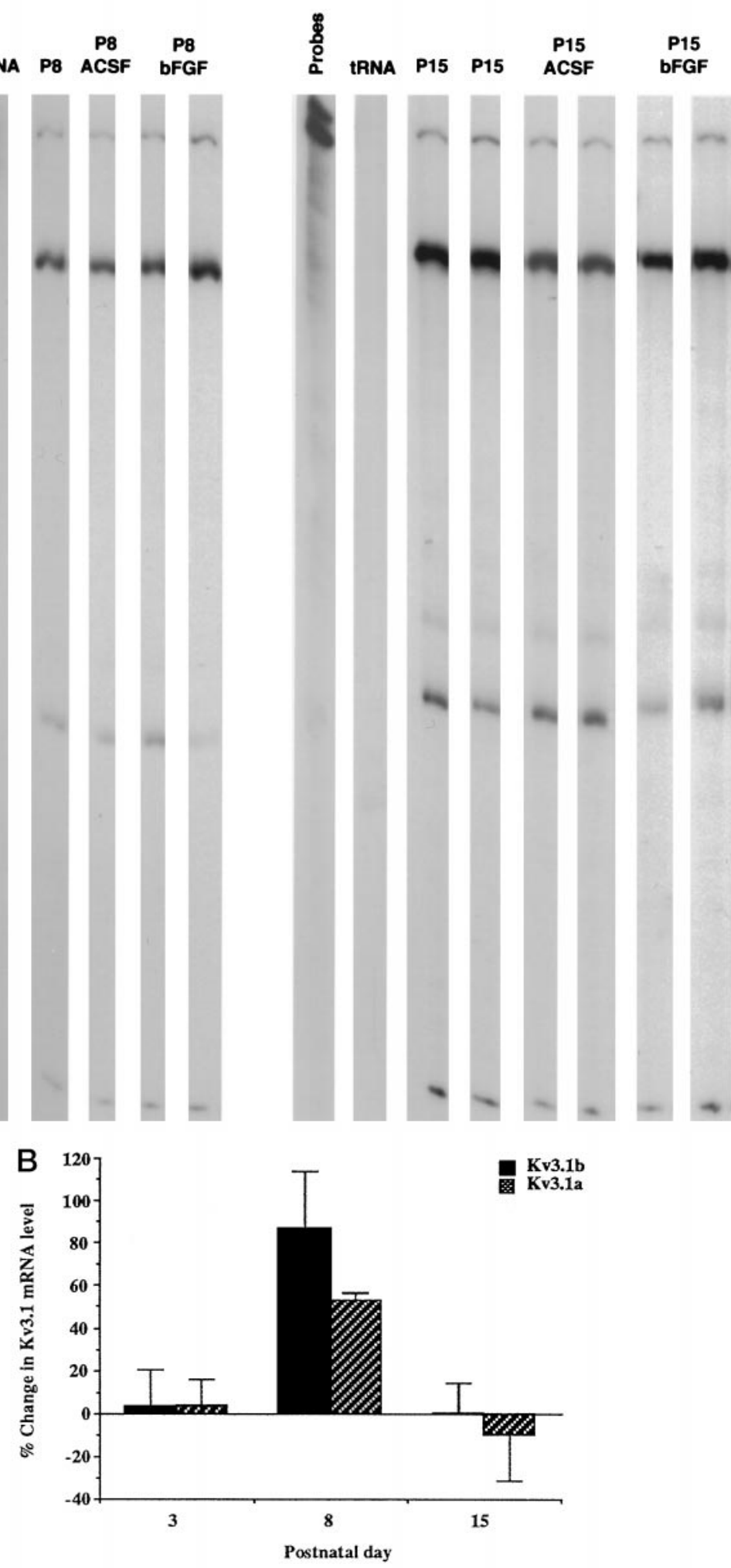

and high-K ACSF suppressed the FGF-induced upregulation of the levels of the Kv3.1a transcript, whereas the increase in Kv3.1b mRNA levels remained unaffected (Fig. $3 A, B$ ).

The selective increase in the levels of the Kv3.1b transcript induced by bFGF with high-K ACSF suggests that different signaling pathways are used for regulation of the transcription of the two Kv3.1 splice variants and that high-K ACSF may selec- 
Table 2. The changes in the Kv3.1a and Kv3.1b mRNA levels induced by neurotrophins and depolarization during development Changes in the levels of the Kv3.1a and Kv3.1b mRNA (\%)

\begin{tabular}{|c|c|c|c|c|c|c|}
\hline \multirow[b]{2}{*}{ Treatment } & \multicolumn{2}{|l|}{ P3 } & \multicolumn{2}{|l|}{$\mathrm{P} 8$} & \multicolumn{2}{|l|}{$\mathrm{P} 15$} \\
\hline & $\mathrm{Kv} 3.1 \mathrm{~b}$ & Kv3.1a & $\mathrm{Kv} 3.1 \mathrm{~b}$ & Kv3.1a & $\mathrm{Kv} 3.1 \mathrm{~b}$ & Kv3.1a \\
\hline BDNF & $61.5 \pm 16.6^{*}$ & $63.7 \pm 38.3$ & $14.4 \pm 11.3$ & $3.5 \pm 23.5$ & $7.9 \pm 19.1$ & $9.7 \pm 42.9$ \\
\hline NT-3 & $25.8 \pm 21.3$ & $43.6 \pm 13.4^{* *}$ & $34.5 \pm 8.3$ & $14.5 \pm 23.2$ & $-8.5 \pm 4.4$ & $0.9 \pm 23.1$ \\
\hline High-K & $14.1 \pm 13.9$ & $40.6 \pm 21.2$ & $8.3 \pm 6.8$ & $7.0 \pm 17.2$ & $-7.5 \pm 13.4$ & $-5.9 \pm 4.1$ \\
\hline
\end{tabular}

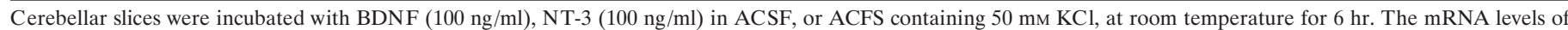

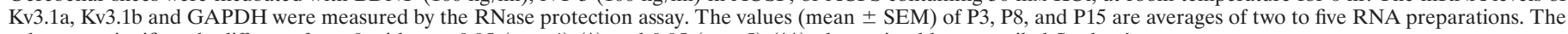
values are significantly different from 0 with $p<0.05(n=4)\left(^{*}\right)$ and $0.05(n=5)(* *)$, determined by two-tailed Student's t test.

tively interrupt signaling pathways that modulate the levels of Kv3.1a mRNA. This hypothesis is supported by the finding that bFGF induces the two splice variants with a different time course. Treatment of slices with bFGF for only $1 \mathrm{hr}$ followed by ACSF for $5 \mathrm{hr}$ produced the same increase in $\mathrm{Kv} 3.1 \mathrm{~b}$ mRNA as treatment with bFGF for $6 \mathrm{hr}$. The increase in Kv3.1a mRNA levels was, however, reduced by the shorter treatment with bFGF (Fig. 3C). Taken together, these data support the notion that regulation of $\mathrm{Kv} 3.1 \mathrm{a}$ and Kv3.1b mRNA levels are mediated by different intracellular signaling pathways.

\section{Regulation of expression of the Kv3.1 splice variants by second messenger pathways}

To identify the intracellular signals that are responsible for the differential regulation of Kv3.1 splice variants, we applied inhibitors of ras (AFC), CaM/kinase (KN-62), the cAMP-dependent protein kinase (PKA; KT5720), PKC (BIM I), and protein synthesis (cycloheximide) during bFGF treatment (Fig. 4). All of these inhibitors completely inhibited the FGF-stimulated elevation of Kv3.1a mRNA levels, suggesting that upregulation of Kv3.1a mRNA may require protein synthesis and activation of ras, CaM/kinase, PKA, and PKC. However, these inhibitors had very different effects on the FGF-induced increase in Kv3.1b mRNA levels. Cycloheximide treatment completely abolished the changes in Kv3.1b mRNA levels, indicating that protein synthesis was necessary. KN-62 appeared to partially reduce the FGFinduced increase in the Kv3.1b transcript. The PKC inhibitor BIM I and inhibitors for ras and PKA did not, however, affect the expression levels of Kv3.1b mRNA, although each of them totally suppressed the elevation of the Kv3.1a transcript. Thus, in contrast to Kv3.1a, the elevation of the Kv3.1b transcript does not require PKC, PKA, and ras activity, again suggesting that different signaling proteins are used in the regulation of the two transcripts.

\section{Inhibition of FGF-induced PKC activity by depolarization}

We have demonstrated that both high potassium and a PKC inhibitor selectively suppress the FGF-induced upregulation of Kv3.1a mRNA at P8. This raises the possibility that bFGF enhances PKC activity in the nucleus and that depolarization inhibits this activation of PKC. To test this hypothesis, we treated P8 cerebellar slices with bFGF alone, with bFGF in high-K ACSF, or with bFGF and BIM I for $2 \mathrm{hr}$. Nuclei were then isolated, and nuclear PKC activity was measured. We found that bFGF alone induced a twofold increase in nuclear PKC activity, which was inhibited by the PKC inhibitor BIM I (Fig. 5). The stimulation of the nuclear PKC activity by bFGF was also prevented by high-K ACSF, consistent with the notion that depolar- ization selectively acts on Kv3.1 transcripts by altering PKC activity. We found that addition of the phorbol ester PMA did not enhance PKC activity in the nuclear fraction (data not shown). This is consistent with the idea that either phorbol esterinsensitive isoforms of PKC are activated, or PKC is already fully activated in the nucleus.

\section{Modulation of PKC activity by depolarization in developing and mature cerebellum}

There are a number of mechanisms by which depolarization could antagonize the FGF-induced increase in nuclear PKC activity. These include direct inhibition of PKC activity, inhibition of PKC translocation to the nucleus, or blockage of pathways that link the bFGF receptor to PKC activation. To test whether depolarization inhibits PKC activity directly, we incubated P8 cerebellar slices in normal medium or in high-K ACSF and measured both PMA-stimulated and PMA-independent PKC activity in tissue homogenates. High-K ACSF produced a modest but significant reduction in phorbol ester-independent $\mathrm{PKC}$ activity $(31 \% ; p<0.05$; Fig. $6 A$ ). Thus, inhibition of PKC activity by high-K ACSF could, at least in part, contribute to the differential regulation of transcription of the Kv3.1 splice variants.

The finding that high-K ACSF inhibits PKC was unexpected, because neuronal activity has been found to activate PKC in some excitable cells (Huang et al., 1992), and depolarization increases the concentration of intracellular calcium that facilitates the activation of PKC. We therefore examined the possibility that depolarization affects PKC activity differently in developing and mature cerebellums. We incubated cerebellar slices of adult animals in ACSF or in high-K ACSF and measured the PKC activity of the homogenates. High-K ACSF treatment that reduced PKC activity in $\mathrm{P} 8$ cerebellum increased $\mathrm{PKC}$ activity in adult cerebellum by $112 \%$ (Fig. $6 B$ ).

The above data suggest that some endogenous inhibitory factors could be present or induced by depolarization in P8 cerebellums but not in those of adults. If such endogenous inhibitory factors are present, then adding P8 homogenate to adult homogenates should reduce their PKC activity. We therefore measured the PKC activity of homogenates from P8 and adult cerebellums individually and then determined the PKC activity of combined homogenates. The PKC activities of combined samples were lower than the sum of the PKC activity of individual homogenates by $70-75 \%$ (Fig. 7). As a control, when two adult homogenates were mixed, no significant change was observed. This result indicates that an endogenous PKC inhibitory factor is present in cerebellum at P8. 

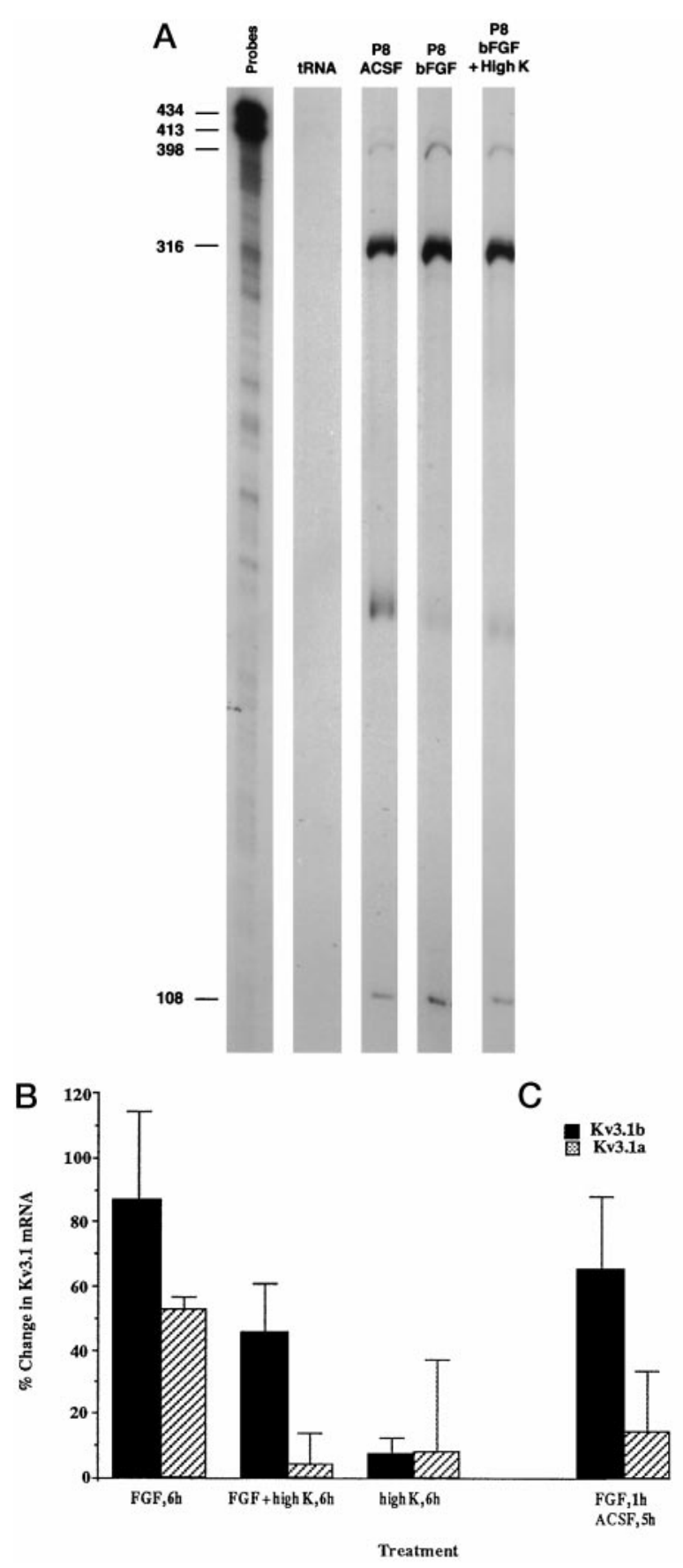

Figure 3. Differential regulation of Kv3.1a and Kv3.1b mRNA at P8 by bFGF and high-K ACSF. $A$, RNase protection analysis of effects of depolarization on the FGF-induced upregulation of Kv3.1a mRNA levels. Cerebellar slices were treated with $100 \mathrm{ng} / \mathrm{ml}$ bFGF in ACSF or with bFGF in high-K ACSF. The bands corresponding to the Kv3.1b, GAPDH, and Kv3.1a mRNAs are 398, 316, and 108 nucleotides, respectively. $B, C$, Summary of effects of depolarization on the FGF-induced changes in the levels of Kv3.1 transcripts. Cerebellar slices were treated with bFGF in ACSF, bFGF in high-K ACSF, or with high-K ACSF alone for $6 \mathrm{hr}(B)$, or with bFGF in ACSF for $1 \mathrm{hr}$ followed by incubation in ACSF for $5 \mathrm{hr}(C)$. The interaction between FGF and high $\mathrm{K}$ treatment is significant $(p<0.05)$ for Kv3.1a by a two-factor ANOVA test $(n=4)$. The change induced by FGF is significantly different from that in control and from that in high-K plus FGF-treated sample $(p<0.01)$, using the Tukey's multiple-comparisons test. The change in the Kv3.1a mRNA levels induced by a $6 \mathrm{hr}$ bFGF treatment $(n=4)$ is different from that induced by a $1 \mathrm{hr}$ bFGF treatment followed by $5 \mathrm{hr}$ incubation in ACSF $(n=3) ; p<0.05$, by a one-tailed Student's $t$ test.

\section{DISCUSSION}

\section{Developmental changes in Kv3.1 mRNA levels}

The expression of potassium channels changes throughout development (Ribera and Spitzer, 1992). In the present study we found a marked increase in the levels of Kv3.1 mRNA in the cerebellum after P8. This is consistent with studies of the development of potassium currents in granule cells in which the Kv3.1 channels are expressed. Hockberger et al. (1987) identified a highthreshold, tetraethylammonium-sensitive potassium current in developing cerebellar granule cells in postnatal explant cultures. This current has all the characteristics expected of a Kv3.1-type current and undergoes a 13-fold increase in amplitude from day 2 to day 18 in vitro. This increase correlates well with the 17 -fold increase in Kv3.1 mRNA levels at P15 relative to P3 in cerebellum.

Computer simulations have suggested that increasing Kv3.1 current density can reduce the duration of individual action potentials without decreasing their amplitude (Kanemasa et al., 1995; Perney and Kaczmarek, 1997). A developmental increase in Kv3.1 expression may therefore allow a mature neuron to generate high-frequency trains of action potentials. The increase in potassium current may also affect the subsequent course of development, as has been proposed for amphibian spinal neurons (O'Dowd et al., 1988; Lockery and Spitzer, 1992). In cerebellar cortex, the migration of granule cells from the external germinal layer to the internal granule layer occurs between P4 and P15, during the time of the greatest increase in Kv3.1 mRNA levels. Migration requires the activity of $\mathrm{N}$-type calcium channels and NMDA receptors and is accompanied by an increase in the levels of intracellular calcium (Komuro and Rakic, 1992, 1993, 1996). Changes in the duration of action potentials produced by the increase in Kv3.1 channels could therefore reduce calcium entry and influence the migration of granule cells after they reach the internal granule layer.

\section{Factors that regulate Kv3.1 expression during development}

Neurotrophins, growth factors, and neuronal activity have been shown to regulate the expression of a number of ion channels in cell lines, including Kv3.1 (Perney and Kaczmarek, 1993). We have now demonstrated that $\mathrm{bFGF}$ and the neurotrophins BDNF and NT-3 upregulate Kv3.1 mRNA levels in intact slices of cerebellum at specific developmental stages. bFGF, BDNF, and NT-3 are present in cerebellum during development (Maisonpierre et al., 1990; Kuzis et al., 1995) and have been shown to promote survival and neurite outgrowth of cultured granule cells (Hatten et al., 1988; Segal et al., 1992). The selective effects of the neurotrophins on Kv3.1 mRNA levels temporally correlate with the neurotrophin responsiveness of granule cells and with the changes in the mRNA levels of the neurotrophin receptors trkB and $t r k C$ in developing granule cells (Segal et al., 1992, 1995). Developmental changes in the expression levels of FGF receptors and their ligands appear to be more complicated. bFGF interacts with four classes of known FGF receptors, FGFR1-4 (Ornitz et al., 1996). One of these, FGFR4, has been reported to be transiently expressed in the external granule layer between P7 and P15 (Miyake et al., 1995) at the time of the FGF-induced upregulation of Kv3.1 mRNA levels. mRNA for another FGF receptor, FGFR1, persists in the internal granule cell layer from P7 to the adult (Wanada et al., 1990). In our experiments, however, bFGF did not change the levels of Kv3.1 mRNA in the cerebellums of older animals. This discrepancy suggests that the actions of 


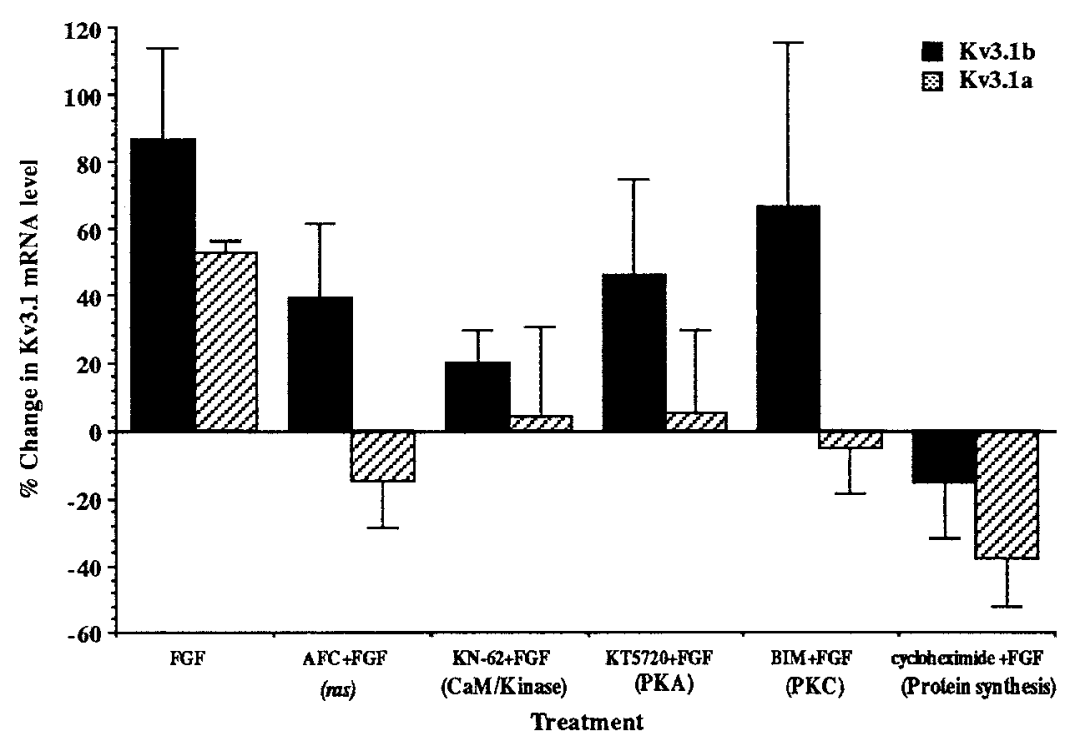

Figure 4. Effects of kinase inhibitors and an inhibitor of protein synthesis on the FGF-induced upregulation of Kv3.1 mRNA in P8 cerebellum. Slices were treated with $100 \mathrm{ng} / \mathrm{ml}$ $\mathrm{bFGF}$ in the presence of $50 \mu \mathrm{M}$ AFC (an inhibitor of ras), 10 $\mu \mathrm{M} \mathrm{KN}-62$ (CaM/kinase inhibitor), $10 \mu \mathrm{M} \mathrm{KT5720} \mathrm{(PKA}$ inhibitor), $2.5 \mu \mathrm{M}$ BIM I (PKC inhibitor), and $5 \mu \mathrm{g} / \mathrm{ml}$ cycloheximide in ACSF for $6 \mathrm{hr}$. The change in Kv3.1a mRNA levels induced by bFGF is significantly different from the changes produced by bFGF in the presence of KT5720, KN-62, AFC, BIM, and cycloheximide, with $p<$ $0.05,0.05,0.005,0.005$, and 0.001 , respectively, using twotailed Student's $t$ tests $(n=3)$. The FGF-induced change in $\mathrm{Kv} 3.1 \mathrm{~b}$ mRNA levels is significantly different from that produced by FGF plus cycloheximide; $p<0.05(n=3)$.

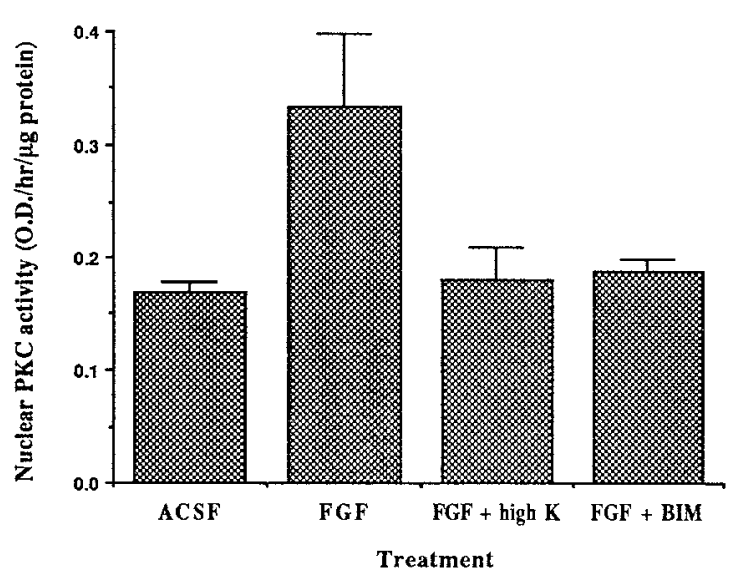

Figure 5. Inhibition of FGF-induced nuclear PKC activation by high-K ACSF. Cerebellar slices were incubated in ACSF alone, in ACSF containing $100 \mathrm{ng} / \mathrm{ml} \mathrm{bFGF}$, in bFGF plus high-K ACSF, or in bFGF plus 2.5 $\mu \mathrm{M}$ PKC inhibitor BIM I at room temperature for $2 \mathrm{hr}$. Nuclei were isolated, and nuclear PKC activity was determined immediately. The nuclear PKC activity from FGF-treated cells differs significantly $(p<$ 0.05 ) from that in control, bFGF plus high $\mathrm{K}$, and bFGF plus BIM samples using a one-tailed Student's $t$ test $(n=3)$.

bFGF on Kv3.1 transcript levels are receptor subtype-specific, or that other factors are also required for the upregulation of Kv3.1 mRNA.

\section{Differential regulation of the expression of Kv3.1 transcripts by extrinsic stimuli}

Although Kv3.1a and Kv3.1b mRNA are expressed in the same cell types (Perney et al., 1992), we have shown that their expression is differentially regulated during development. The longer $\mathrm{C}$-terminal domain of the Kv3.1b protein contains two additional consensus sites for phosphorylation by protein kinase $\mathrm{C}$ and two for casein kinase II (Luneau et al., 1991), suggesting that the two forms of Kv3.1 may be differentially regulated. In addition, the C-terminal region may specifically interact with other membraneassociated proteins, as has been shown for other ion channels (Kim et al., 1995, 1996), leading to the differential localization of the splice variants at the subcellular level.

Our results suggest that the expression of Kv3.1a and Kv3.1b mRNAs is regulated by different intracellular signals. Inhibi- tion of PKC, PKA, CaM/kinase, and ras each completely blocked the FGF-induced upregulation of Kv3.1a mRNA. This indicates that all of these factors may be required for the regulation of Kv3.1a mRNA levels by acting either sequentially or simultaneously in a single signaling pathway. In contrast, elevation of Kv3.1b mRNA levels did not depend on activation of PKC, PKA, and ras. Previous experiments have shown that transfection of AtT20 cells with a ras oncogene increases the levels of Kv3.1a mRNA and not those of Kv3.1b mRNA (Hemmick et al., 1992), supporting the idea that a ras pathway differentially regulates Kv3.1a expression.

The upregulation of Kv3.1a and Kv3.1b expression by bFGF could occur at the level of transcription. The effects of PKA and $\mathrm{CaM} /$ kinase may be mediated by the $\mathrm{cAMP} /$ calcium response element in the promoter of the Kv3.1 gene (Gan et al., 1996). In addition, because inhibition of protein synthesis completely blocked the FGF-induced elevation of both Kv3.1a and Kv3.1b mRNA levels, enhanced transcription of Kv3.1 may require the products of immediate early genes. The selective suppression of the increase in Kv3.1a mRNA by various kinase inhibitors could also involve the modulation of alternative splicing. Phosphorylation of some of the serine- and arginine-rich splicing factors by kinases, such as Clk/Sty and SRPK1, regulates their activity and their intracellular distribution (Gui et al., 1994; Colwill et al., 1996). Whether PKC, PKA, and ras regulate alternative splicing directly, however, remains to be elucidated.

Our findings also suggest that depolarization plays an important role in the differential regulation of Kv3.1 transcripts. Depolarization has been shown to alter the expression of receptors and ion channels in cultured granule cells and other cell types (Levitan et al., 1995; Vallano et al., 1996). In this study we found that depolarization alone did not modulate Kv3.1 expression but inhibited the FGF-induced signaling pathway that increases Kv3.1a mRNA, resulting in a selective increase in Kv3.1b mRNA. It is possible that, after granule cell migration, the formation of synapses with mossy fibers provides the electrical stimulation that selectively modulates the expression levels of the Kv3.1 splice variants. We do not yet know whether the effects of elevated potassium ions on cerebellar slices result from the direct depolarization of granule cells or are mediated by substances released from other cells. 
A
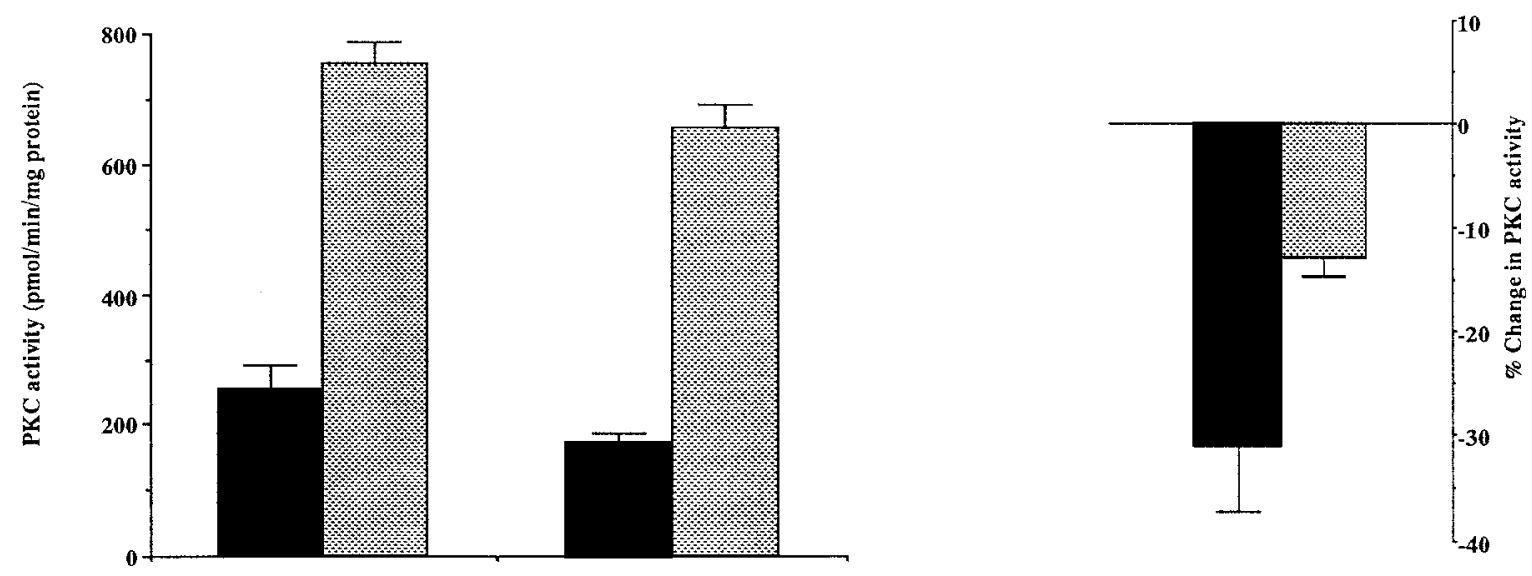

B
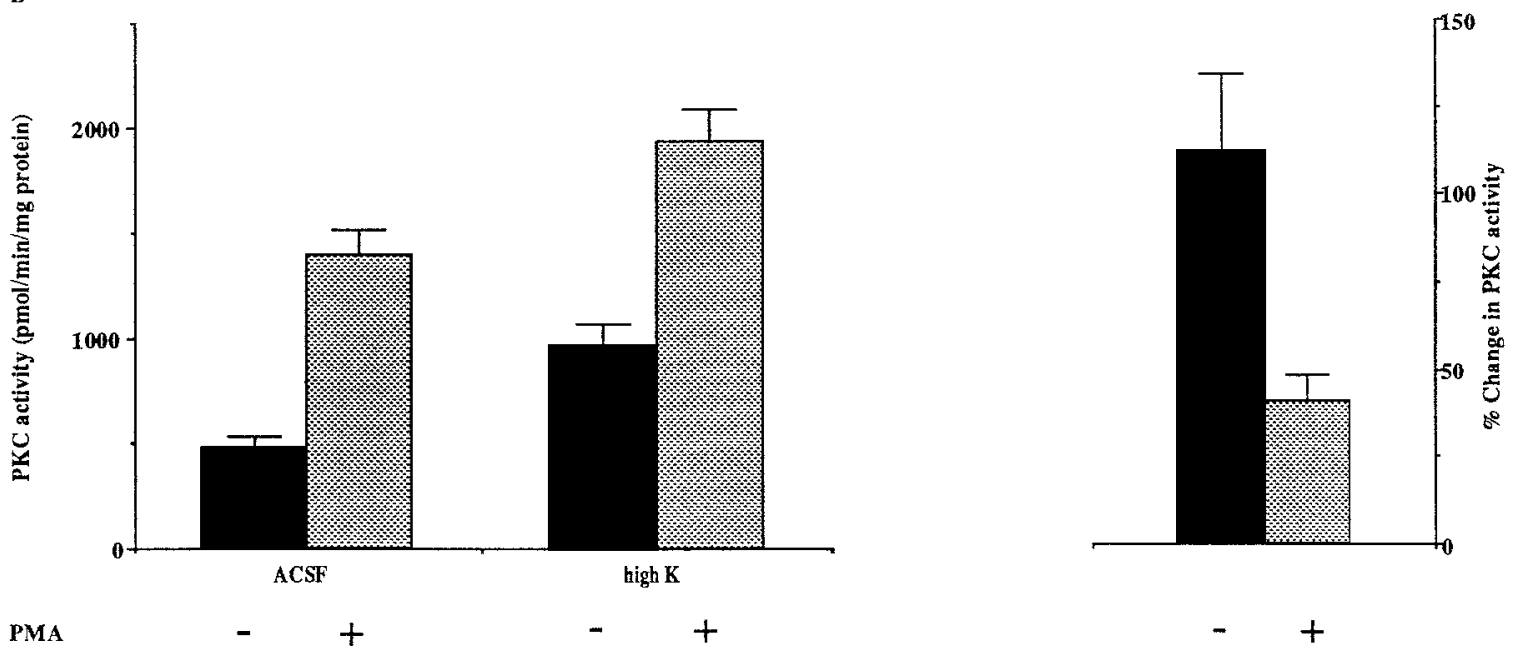

Figure 6. The effects of high-K ACSF treatment on PKC activity of $\mathrm{P} 8(A)$ and adult $(B)$ cerebellum. P8 and adult cerebellar slices were incubated in ACSF or high-K ACSF for $2 \mathrm{hr}$. PKC activity of homogenates was determined in the presence or absence of $10 \mu \mathrm{M}$ PMA. Changes in PKC activity were calculated according to the following equation: (PKC activity (high K)/PKC activity (ACSF) -1$) \times 100 \%$. The PMA-independent PKC activity in control (ACSF) sample at P8 is significantly different from that in the high-K treated sample; $p<0.05$, by a one-tailed Student's $t$ test. The interaction between age of the animal and the effects of high $\mathrm{K}$ treatment is significant; $p<0.05$ for PMA-independent PKC activity; $p<0.01$ for the PKC activity in the presence of PMA, using a two-factor ANOVA test $(n=4)$. The PKC activity in adult high-K-treated sample is significantly different from that in the adult control (ACSF) and in the P8 high-K-treated sample; $p<0.01$ (without PMA) and $p<0.01$ (with PMA). PKC activity in the adult control is different from that in P8 control; $p<0.05$ (without PMA) and $p<0.01$ (with PMA), by a Tukey's multiple-comparisons test. The depolarizationinduced change in PKC activity in the absence and presence of PMA in the adult is significantly different from that at P8; $p<0.001$ (without PMA) and $p<0.01$ (with PMA), by a two-tailed Student's $t$ test.

We have also provided evidence that in the presence of bFGF the differential action of depolarization on Kv3.1a and Kv3.1b transcripts is mediated by PKC. First, bFGF alone stimulated nuclear PKC activity and upregulated levels of both Kv3.1a and Kv3.1b mRNAs. Inhibition of PKC activity suppressed the FGFinduced increase in the Kv3.1a mRNA levels but did not affect the increase in Kv3.1b mRNA. Furthermore, depolarization inhibited PKC activation by bFGF and selectively abolished the increase in Kv3.1a mRNA without affecting Kv3.1b mRNA expression. These results suggest that the stimulation of nuclear PKC by bFGF is inhibited by depolarization and that this inhibition selectively blocks the signaling pathway required for the upregulation of Kv3.1a mRNA.
Figure 7. The inhibitory effects of P8 homogenates on PKC activity. PKC activity of P8 and adult cerebellar homogenates, and of homogenates of P8 and adult cerebellar slices that were preincubated in ACSF or high-K ACSF, was determined individually. The homogenates of two samples $(a, b)$, indicated on the $x$-axis, were then mixed, and the PKC activity of the combined sample $(a, b)$ was measured. The PKC activity in the combined sample and the sum of the PKC activity of the two samples is shown in $A$ (without PMA) and $B$ (with $10 \mu \mathrm{M}$ PMA). The sum of the PKC activity in the adult (high K) sample and in P8, P8 (ACSF), P8 (high $\mathrm{K})$ samples is significantly different from that in the combined samples, adult (high K) plus P8, adult (high K) plus P8 (ACSF), and adult (high K) plus P8 (high K), with $p<0.05,0.01$, and 0.002 (without PMA), respectively, and $p<0.01,0.05$, and 0.02 (with PMA), respectively $(n=3)$, by a two-tailed Student's $t$ test. The PKC activity in the combined sample, P8 plus P8 (high K), is also different from the sum of PKC (Figure legend continues) 

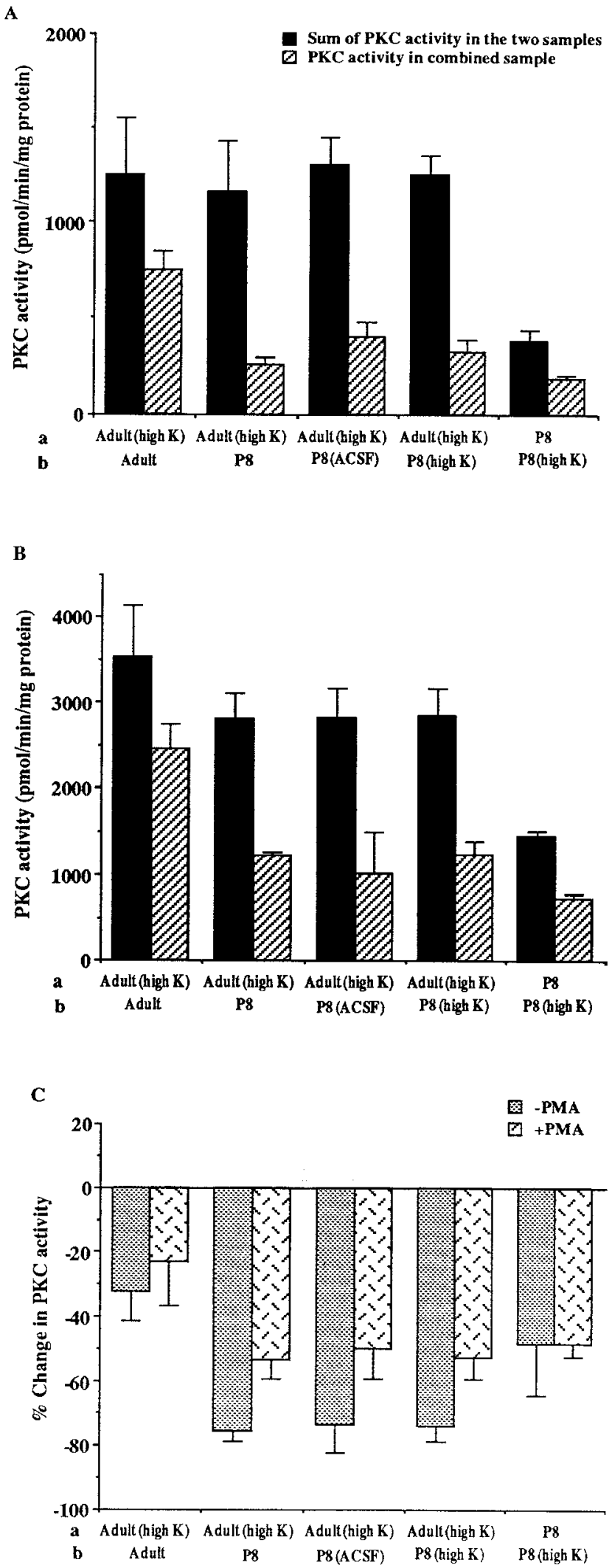

activity in the P8 and in P8 (high $\mathrm{K}$ ) samples; $p<0.05$ (without PMA) and $p<0.01$ (with PMA) $(n=3)$, by a two-tailed Student's $t$ test. Changes in PKC activity resulting from the mixing of the two samples $(C)$ were calculated, using the equation $[(a+b /(a+b))-1] \times 100 \%$.

\section{Developmental regulation of PKC activity}

The effects of depolarization on PKC activity are responsible for the inhibition of nicotinic acetylcholine receptor $(\mathrm{AChR}) \alpha$ gene expression by electrical activity (Klarsfeld et al., 1989; Huang et al., 1992). In contrast to its effects in P8 cerebellum, depolarization of muscle increases PKC activity, thereby inhibiting the expression of the AChR. Our results indicate that the inhibition of PKC by depolarization occurs only in developing cerebellum, and that an inhibitor of PKC is present in P8 cerebellar homogenates but is absent in adults. This inhibitor could be one of the several endogenous PKC inhibitors that have been isolated (Pearson et al., 1990; Toker et al., 1990). Whether this endogenous inhibitor contributes to suppression of Kv3.1a during development will have to await determination of the full pathway by which bFGF regulates the Kv3.1a transcript.

In summary, we have demonstrated that the differential regulation of Kv3.1 splice variants is mediated by protein kinases and depolarization. Similar molecular mechanisms may underlie the regulation of other voltage- and ligand-gated channels that undergo a change in the expression of their splice variants during development. Because many neurons are known to contain neurotrophins, their release in combination with neuronal stimulation could provide the two signals required for selective expression of channel isoforms.

\section{REFERENCES}

Ames BN (1966) Assay of inorganic phosphate, total phosphate and phosphatases. Methods Enzymol 8:115-118.

Ausubel FM, Brent R, Kingston RE, Moore DD, Seidmand JG, Smith JA, Struhl K (1990) Current protocols in molecular biology, pp 4.7.14.8.3. New York: Wiley.

Chomcyznski P, Sacchi N (1987) Single-step method of RNA isolation by guanidinium thiocyanate-phenol-chloroform extraction. Anal Biochem 162:156-159.

Colwill K, Pawson T, Andrews B, Prasad J, Manley JL, Bell JC, Duncan PI (1996) The Clk/Sty protein kinase phosphorylates SR splicing factors and regulates their intranuclear distribution. EMBO J 15:265-275.

Gan L, Perney TM, Kaczmarek LK (1996) Cloning and characterization of the promoter for a potassium channel expressed in high frequency firing neurons. J Biol Chem 271:5859-5865.

Grissmer S, Ghanshani S, Dethlefs B, McPherson JD, Wasmuth JJ, Gutman GA, Cahalan MD, Chandy KG (1992) The Shaw-related potassium channel gene, Kv3.1, on human chromosome 11, encodes the type $1 \mathrm{~K}^{+}$channel in T cells. J Biol Chem 267:20971-20979.

Gui J-F, Lane WS, Fu X-D (1994) A serine kinase regulates intracellular localization of splicing factors in the cell cycle. Nature 369:678-692.

Hatten ME, Lynch M, Rydel RE, Sanchez J, Joseph-Silverstein J, Moscatelli D, Rifkin DB (1988) In vitro neurite extension by granule cells is dependent upon astroglial-derived fibroblast growth factor. Dev Biol 125:280-289.

Hemmick LM, Perney TM, Flamm RE, Kaczmarek LK, Birnberg NC (1992) Expression of the H-ras oncogene induces potassium conductance and neuron-specific potassium channel mRNA in the AtT20 cell. J Neurosci 12:2007-2014.

Hockberger PE, Tseng H-Y, Connor JA (1987) Immunocytochemical and electrophysiological differentiation of rat cerebellar granule cells in explant cultures. J Neurosci 7:1370-1383.

Huang C-F, Tong J, Schmidt J (1992) Protein kinase C couples membrane excitation to acetylcholine receptor gene inactivation in chick skeletal muscle. Neuron 9:671-678.

Kanemasa T, Gan L, Perney TM, Wang L-Y, Kaczmarek LK (1995) Electrophysiological and pharmacological characterization of a mammalian Shaw channel expressed in NIH 3 T3 fibroblasts. J Neurophysiol 74:207-217.

Kim E, Niethammer M, Rothschild A, Jan YN, Sheng M (1995) Clustering of Shaker-type $\mathrm{K}^{+}$channels by interaction with a family of membrane-associated guanylate kinase. Nature 378:85-88.

Kim E, Cho K-O, Rothschild A, Sheng M (1996) Heteromultimeriza- 
tion and NMDA receptor-clustering activity of Chapsyn-110, a member of the PSD-95 family of proteins. Neuron 17:103-113.

Klarsfeld A, Laufer R, Fontaine B, Devellers-Thiery A, Dubreuil C, Changeux JP (1989) Regulation of muscle AChR a subunit gene expression by electrical activity: involvement of protein kinase $\mathrm{C}$ and $\mathrm{Ca}^{2+}$. Neuron 2:1229-1236.

Komuro H, Rakic P (1992) Selective role of N-type calcium channels in neuronal migration. Science 257:806-809.

Komuro H, Rakic P (1993) Modulation of neuronal migration by NMDA receptors. Science 260:95-97.

Komuro H, Rakic P (1996) Intracellular $\mathrm{Ca}^{2+}$ fluctuations modulate the rate of neuronal migration. Neuron 17:275-285.

Kuzis K, Reed S, Cherry NJ, Woodward WR, Eckenstein FP (1995) Developmental time course of acidic and basic fibroblast growth factors' expression in distinct cellular populations of the rat central nervous system. J Comp Neurol 358:142-153.

Levitan ES, Gealy R, Trimmer JS, Takimoto K (1995) Membrane depolarization inhibits Kv1.5 voltage-gated $\mathrm{K}^{+}$channel gene transcription and protein expression in pituitary cells. J Biol Chem 270:6036-6041.

Lockery SR, Spitzer NC (1992) Reconstruction of action potential development from whole cell currents of differentiating spinal neurons. J Neurosci 12:2268-2287.

Luneau CJ, Williams JB, Marshall J, Levitan ES, Oliva C, Smith JS, Antanavage J, Folander K, Stein RB, Swanson R, Kaczmarek LK, Buhrow SA (1991) Alternative splicing contributes to $\mathrm{K}^{+}$channel diversity in the mammalian central nervous system. Proc Natl Acad Sci USA 88:3932-3936.

Maisonpierre PC, Belluscio L, Friedman B, Alderson RF, Lindsay RM, Yancopoulos GD (1990) NT-3, BDNF, and NGF in the developing rat nervous system: parallel as well as reciprocal patterns of expression. Neuron 5:501-509.

Miyake A, Minami M, Satoh M, Ohta M, Itoh N (1995) Transient expression of FGF receptor-4 mRNA in the rat cerebellum during postnatal development. Mol Brain Res 31:95-100.

O'Dowd DK, Ribera AB, Spitzer NC (1988) Development of voltagedependent calcium, sodium, and potassium currents in Xenopus spinal neurons. J Neurosci 8:792-805.

Ornitz DM, Xu J, Colvin JS, McEwen DG, MacArthur CA, Coulier F, Gao G, Goldfarb M (1996) Receptor specificity of the fibroblast growth factor family. J Biol Chem 271:15292-15297.

Pearson JD, Dewald DB, Mathews WR, Mozier NM, Zurcher-Neely HA, Heinrikson RL, Morris MA, McCubbin WD, McDonald JR, Fraser ED, Vogel HJ, Kay CM, Walsh MP (1990) Amino acid sequence and characterization of a protein inhibitor of protein kinase C. J Biol Chem 265:4583-4591.

Perney TM, Kaczmarek LK (1993) Expression and regulation of mammalian K channel genes. Semin Neurosci 5:135-145.
Perney TM, Kaczmarek LK (1997) Localization of a high threshold potassium channel in the rat cochlear nucleus. J Comp Neurol 386:178-202.

Perney TM, Marshall J, Martin KA, Hockfiels S, Kaczmarek LK (1992) Expression of the mRNAs for the Kv3.1 potassium channel gene in the adult and developing rat brain. J Neurophysiol 3:756-766.

Post RL, Sen AK (1987) Sodium and potassium-stimulated ATPase. Methods Enzymol 10:762-768.

Ribera AB, Spitzer NC (1992) Developmental regulation of potassium channels and the impact on neuronal differentiation. In: Ion channels (Narahashi T, ed), pp 1-38. New York: Plenum.

Segal RA, Takahashi H, MaKay RDG (1992) Changes in neurotrophin responsiveness during the development of cerebellar granule neurons. Neuron 9:1041-1052.

Segal RA, Pomeroy SL, Stiles CD (1995) Axonal growth and fasciculation linked to differential expression of BDNF and NT3 receptors in developing cerebellar granule cells. J Neurosci 15:4970-4981.

Sokoloff L, Reivich M, Kennedy C, Des Rosiers MH, Patlak CS, Pettigrew KD, Sakurada O, Shinohara M (1977) The $\left[{ }^{14} \mathrm{C}\right]$ deoxyglucose method for the measurement of local cerebral glucose utilization: theory, procedure, and normal values in the conscious and anesthetized albino rat. J Neurochem 28:897-916.

Tanaka C, Nishizuka Y (1994) The protein kinase C family for neuronal signaling. Annu Rev Neurosci 17:551-567.

Thompson RJ (1987) Isolation procedures and in vitro applications of cell nuclei from the mammalian brain. In: Neurochemistry: a practical approach (Turner AJ, Bachelard HS, eds), pp 225-242. Oxford: IRL.

Toker A, Ellis CA, Sellers LA, Aitken A (1990) Protein kinase C inhibitor proteins: purification from sheep brain and sequence similarity to lipocortins and 14-3-3 protein. Eur J Biochem 191:421-429.

Vallano ML, Lambolez B, Audinat E, Rossier J (1996) Neuronal activity differentially regulates NMDA receptor subunit expression in cerebellar granule cells. J Neurosci 16:631-639.

Wanada A, Johnson EM, Milbrandt J (1990) Localization of FGF receptor mRNA in the adult rat central nervous system by in situ hybridization. Neuron 5:267-281.

Wang Y, Roach PJ (1993) Purification and assay of mammalian protein (serine/threonine) kinase. In: Protein phosphorylation: a practical approach (Hardie DG, ed), pp 121-144. Oxford: Oxford UP.

Weiser M, Bueno E, Sekirnjak C, Martone ME, Baker H, Hillman BD, Chen S, Thornhill W, Ellisman M, Rudy B (1995) The potassium channel subunit Kv3.1b is localized to somatic and axonal membranes of specific populations of CNS neurons. J Neurosci 15:4298-4314.

Yokoyama S, Imoto K, Kawamura T, Higashida H, Iwabe N, Miyata T, Numa S (1989) Potassium channels from NG108-15 neuroblastomaglioma hybrid cells. Primary structure and functional expression of cDNAs. FEBS Lett. 259:37-42. 